\title{
Brazilian Mangroves: Blue Carbon Hotspots of National and Global Relevance to Natural Climate Solutions
}

\section{OPEN ACCESS}

Edited by:

Dominic A. Andradi-Brown, World Wildlife Fund, United States

Reviewed by:

Steven Canty,

Smithsonian Marine Station (SMS),

United States

Luiz Drude Lacerda,

Federal University of Ceara, Brazil Jacob Bukoski,

University of California, Berkeley,

United States

*Correspondence:

Andre S. Roval

arovai1@/su.edu

TORCID:

Andre S. Rovai

orcid.org/0000-0003-4117-2055

Robert R. Twilley

orcid.org/0000-0002-6173-6033

Thomas A. Worthington orcid.org/0000-0002-8138-9075

Pablo Riul

orcid.org/0000-0003-4035-1975

Specialty section:

This article was submitted to

Tropical Forests,

a section of the journal

Frontiers in Forests and Global

Change

Received: 30 September 2021 Accepted: 09 December 2021

Published: 03 January 2022

Citation:

Rovai AS, Twilley RR,

Worthington TA and Riul P (2022)

Brazilian Mangroves: Blue Carbon

Hotspots of National and Global

Relevance to Natural Climate

Solutions.

Front. For. Glob. Change 4:787533.

doi: 10.3389/ffgc.2021.787533
Andre S. Rovai ${ }^{1 * t}$, Robert R. Twilley ${ }^{1 \dagger}$, Thomas A. Worthington ${ }^{2+}$ and Pablo Riul ${ }^{3+}$

\begin{abstract}
1 Department of Oceanography and Coastal Sciences, College of the Coast \& Environment, Louisiana State University, Baton Rouge, LA, United States, ${ }^{2}$ Conservation Science Group, Department of Zoology, University of Cambridge, Cambridge, United Kingdom, ${ }^{3}$ Departamento de Sistemática e Ecologia, Centro de Ciências Exatas e da Natureza, Universidade Federal da Paraíba, João Pessoa, Brazil
\end{abstract}

Mangroves are known for large carbon stocks and high sequestration rates in biomass and soils, making these intertidal wetlands a cost-effective strategy for some nations to compensate for a portion of their carbon dioxide $\left(\mathrm{CO}_{2}\right)$ emissions. However, few countries have the national-level inventories required to support the inclusion of mangroves into national carbon credit markets. This is the case for Brazil, home of the second largest mangrove area in the world but lacking an integrated mangrove carbon inventory that captures the diversity of coastline types and climatic zones in which mangroves are present. Here we reviewed published datasets to derive the first integrated assessment of carbon stocks, carbon sequestration rates and potential $\mathrm{CO}_{2 \text { eq }}$ emissions across Brazilian mangroves. We found that Brazilian mangroves hold $8.5 \%$ of the global mangrove carbon stocks (biomass and soils combined). When compared to other Brazilian vegetated biomes, mangroves store up to 4.3 times more carbon in the top meter of soil and are second in biomass carbon stocks only to the Amazon forest. Moreover, organic carbon sequestration rates in Brazilian mangroves soils are 15-30\% higher than recent global estimates; and integrated over the country's area, they account for $13.5 \%$ of the carbon buried in world's mangroves annually. Carbon sequestration in Brazilian mangroves woody biomass is 10\% of carbon accumulation in mangrove woody biomass globally. Our study identifies Brazilian mangroves as a major global blue carbon hotspot and suggest that their loss could potentially release substantial amounts of $\mathrm{CO}_{2}$. This research provides a robust baseline for the consideration of mangroves into strategies to meet Brazil's intended Nationally Determined Contributions.

Keywords: Brazil, mangrove forests, blue carbon, hotspot, $\mathrm{CO}_{2}$ equivalent emissions

\section{INTRODUCTION}

Climate change velocity has outpaced models' predictions spurring the implementation of natural climate solutions policies centered on ecosystems self-organizing properties to mitigate fossil fuels emissions and ensue adaptive capacity to future alterations in the climate system. Natural ecosystems have evolved mechanisms that allow them to shift among alternate states while 
remaining functional over geomorphic timescales (Holling, 1973). Such processes are evident in dynamic coastal sedimentary environments, which alternate between vegetated and unvegetated states (e.g., saltmarshes and mangroves versus mudflats and saltflats) in response to climate and millennialscale changes in sea levels (Gabler et al., 2017; Saintilan et al., 2020). In particular, where sediment yield to coastal oceans has not been impaired and coastal floodplains still allows for inland expansion, rising sea levels can increase accommodation space along mangrove- and marsh-dominated environments sustaining continuous burial of terrigenous and marine organic sediments (Rogers et al., 2019).

Among tidal saline wetlands, mangroves are known for high rates of carbon sequestration in soils (mean $=222 \mathrm{gC} \mathrm{m}^{-2}$ $\mathrm{yr}^{-1}$; Jennerjahn, 2020; MacKenzie et al., 2020; Wang et al., 2020), that are 50 times higher than reported for terrestrial tropical and temperate forested biomes (mean $=4.5 \mathrm{gC} \mathrm{m}^{-2}$ $\mathrm{yr}^{-1}$; McLeod et al., 2011). Combined with comparable carbon sequestration rates in woody biomass (mean $=82.7 \mathrm{gC} \mathrm{m}^{-2}$ $\mathrm{yr}^{-1}$, range $=13-2,160 \mathrm{gC} \mathrm{m}^{-2} \mathrm{yr}^{-1}$; Xiong et al., 2019), these intertidal wetlands can be a cost-effective strategy for some nations to compensate for part of their carbon dioxide $\left(\mathrm{CO}_{2}\right)$ emissions (Taillardat et al., 2018). To date, however, few countries have the country-level inventories required to support the inclusion of coastal wetlands into national carbon credit markets (e.g., Holmquist et al., 2018 for the United States and Serrano et al., 2019 for Australia). Moreover, global estimates generally focus on carbon stocks within either soil or biomass (Hutchison et al., 2014; Jardine and Siikamäki, 2014; Atwood et al., 2017; Rovai et al., 2018, 2021b; Sanderman et al., 2018; Tang et al., 2018; Simard et al., 2019; Kauffman et al., 2020), which are important to determine potential $\mathrm{CO}_{2 \mathrm{eq}}$ emissions from mangrove forest loss (see Adame et al., 2021), but do not provide comparable information in terms of mitigating current emission rates. Further, global estimates often do not accurately quantify within-country variability, relying, in many cases, on averaged reference values or model-based generalizations to extrapolate predictions to data-poor or dataabsent nations when harnessing national datasets would be more appropriate to inform country-specific conservation targets (Worthington et al., 2020a).

Brazil is home to the second largest mangrove area in the world, with forests distributed across diverse coastal morphology and climate gradients (Hamilton and Casey, 2016; Worthington et al., 2020b). Despite accounting for over 9\% of the world's mangroves, Brazil still lacks an integrated inventory of carbon stocks and carbon sequestration rates that capture the diversity of coastline types and climatic zones in which mangroves are present. To fill this gap, we performed a comprehensive review of published global datasets to derive within-country estimates of carbon stocks and sequestration rates in mangrove soils and biomass that represent both geographic gradients and administrative divisions in Brazil. In addition to delivering state-level estimates, we provide a direct comparison between mangroves and Brazil's other major vegetated biomes, identifying mangroves as a major carbon hotspot that can help meet intended
Nationally Determined Contributions (NDC's), in addition to their significance as global coastal carbon sinks.

\section{MATERIALS AND METHODS}

\section{Data Acquisition \\ Geospatial Datasets and Analyses: Carbon Stocks in Biomass and Soils}

Global mangrove aboveground biomass (AGB) and soil organic carbon stock (SOC) values were retrieved from various independent datasets that have explicitly mapped the spatial distribution parameters' (Table 1). These global datasets were subsetted for Brazilian mangroves, and median statistics were computed from grided or vectorized datasets where available or directly from the original references. Where possible, uncertainties were assessed on the basis of bootstrapped 95\% confidence intervals for medians using the bias corrected and accelerated (BCa) method (Carpenter and Bithell, 2000; Mangiafico, 2021).

As noted elsewhere (Bukoski et al., 2020), due to the scarcity of field observations there are no regional or global mangrove belowground biomass (BGB) maps. Thus, to be consistent with previous studies, we used a BGB:AGB ratio of 0.5 to estimate BGB across the world's mangroves (IPCC, 2014; Hamilton and Friess, 2018; Rovai et al., 2021b). Further, biomass (both AGB and BGB) was converted to carbon units using a conversion factor of 0.475 (Hamilton and Friess, 2018).

To warrant direct comparison among independent sources, we standardized per-area $\left(\mathrm{MgC} \mathrm{ha}^{-1}\right)$ and total ( $\mathrm{TgC}$ or $\mathrm{PgC}$ ) carbon stock estimates across $\mathrm{AGB}$ and SOC datasets using a conservative mangrove extent of 82,849 and $7,675 \mathrm{~km}^{2}$ for the world's and Brazilian mangroves, respectively (Table 1; after Hamilton and Casey, 2016 but see Hamilton et al., 2018; Worthington et al., 2020a for comprehensive discussions on existing mangrove extent databases).

Biomass (AGB and BGB) and SOC (top 1 meter) stock estimates for Brazilian mangroves used throughout this study were computed from Rovai et al. (2018, 2021b) respectively, given the comparatively larger number of observations ( $>900$ forest plots for $\mathrm{AGB}$ and $>65$ sites for SOC stocks distributed only within Brazil's mangroves; Supplementary Table 1) used in these studies. It is noteworthy that mean AGB and SOC estimates for global and Brazilian mangroves are consistent to mean values computed among previous studies (Table 1). Biomass (AGB and BGB) and SOC (top 1 meter) density in other Brazilian vegetated biomes (Amazon forest, Atlantic forest, Pampa grasslands, Cerrado savannas, Pantanal wetlands, and Caatinga forests) were extracted from harmonized biomass (Spawn et al., 2020) and soil (Hiederer and Köchy, 2011) databases. Due to some overlap between spatial datasets, cells containing mangroves were excluded when computing biomass and SOC density estimates for other Brazilian vegetated biomes. Global datasets were clipped to Brazil's territory, split by state-level administrative divisions and classified into vegetated biomes 
TABLE 1 | Published above- and belowground biomass (AGB and BGB), and soil organic carbon (SOC) stock estimates for global and Brazilian mangroves.

\begin{tabular}{|c|c|c|c|c|c|c|c|c|}
\hline \multirow[t]{2}{*}{ Source } & \multicolumn{2}{|c|}{ Mean AGB (MgC ha-1) } & \multicolumn{2}{|c|}{ Mean BGB (MgC ha-1) } & \multicolumn{2}{|c|}{ Mean SOC $(\mathrm{MgC} \mathrm{ha-1)}$} & & \\
\hline & Global & Brazil & Global & Brazil & Global & Brazil & & \\
\hline Rovai et al., 2018, 2021b & 78 & 66 & 39 & 33 & $297^{a}$ & $241^{a}$ & & \\
\hline Kauffman et al., 2020 & $115^{\mathrm{b}}$ & $125^{b}$ & $741^{b}$ & $347^{b}$ & 334 & 155 & & \\
\hline Simard et al., 2019 & 58 & 42 & 29 & 21 & $283^{c}$ & & & \\
\hline Hamilton and Friess, 2018 & 98 & & 49 & & & & & \\
\hline Tang et al., 2018 & 69 & 78 & 42 & 31 & & & & \\
\hline Sanderman et al., 2018 & & & & & 361 & 358 & & \\
\hline Atwood et al., 2017 & & & & & 283 & 308 & & \\
\hline Hutchison et al., 2014 & 87 & 80 & 34 & 30 & 447 & & & \\
\hline Jardine and Siikamäki, 2014 & & & & & 369 & 342 & & \\
\hline Overall mean & $78 \pm 7$ & $67 \pm 9$ & $39 \pm 3$ & $29 \pm 3$ & $329 \pm 16$ & $281 \pm 37$ & & \\
\hline \multirow[t]{2}{*}{ Source } & \multicolumn{2}{|c|}{ Total AGB (PgC) } & \multicolumn{2}{|c|}{ Total BGB (PgC) } & \multicolumn{2}{|c|}{ Total SOC (PgC) } & \multicolumn{2}{|c|}{ Ecosystem-level C (PgC) } \\
\hline & Global & Brazil & Global & Brazil & Global & Brazil & Global & Brazil \\
\hline Rovai et al., 2018, 2021b & 0.81 & 0.06 & 0.41 & 0.03 & $2.26^{a}$ & $0.16^{a}$ & 3.48 & 0.25 \\
\hline Kauffman et al., 2020 & 0.95 & 0.05 & $2.90^{\mathrm{b}}$ & $0.13^{b}$ & 2.70 & 0.12 & $6.55^{\mathrm{b}}$ & $0.30^{\mathrm{b}}$ \\
\hline Simard et al., 2019 & 0.46 & 0.03 & 0.23 & 0.02 & $2.14^{c}$ & & 2.83 & \\
\hline Hamilton and Friess, 2018 & 0.8 & & 0.41 & & $2.96^{d}$ & & 4.17 & 0.39 \\
\hline Tang et al., 2018 & 0.56 & 0.06 & 0.34 & 0.02 & & & & \\
\hline Sanderman et al., 2018 & & & & & 3.80 & 0.27 & & \\
\hline Atwood et al., 2017 & & & & & 2.60 & 0.24 & & \\
\hline Hutchison et al., 2014 & 0.72 & 0.06 & 0.28 & 0.02 & 3.64 & & 4.64 & \\
\hline Jardine and Siikamäki, 2014 & & & & & 2.96 & 0.26 & & \\
\hline Overall mean & $0.72 \pm 0.073$ & $0.05 \pm 0.006$ & $0.33 \pm 0.035$ & $0.02 \pm 0.003$ & $2.99 \pm 0.25$ & $0.21 \pm 0.03$ & $3.78 \pm 0.40$ & $0.32 \pm 0.07$ \\
\hline Brazil's \% of global & \multicolumn{2}{|c|}{$6.9 \%$} & \multicolumn{2}{|c|}{$6.1 \%$} & \multicolumn{2}{|c|}{$7.0 \%$} & \multicolumn{2}{|c|}{$8.5 \%$} \\
\hline
\end{tabular}

${ }^{a}$ Based on Rovai et al. (2018).

${ }^{b}$ Not included in the overall mean computation since per unit area values were $>30$ and $>90 \%$ higher than mean AGB and SOC values computed from all other studies. ${ }^{c}$ Based on Atwood et al. (2017); not included in the overall mean computation.

'Based on Jardine and Siikamäki (2014); not included in the overall mean computation.

according to the Brazilian Geography and Statistics Institute databases (IBGE, 2019).

\section{Literature Search: Carbon Sequestration in Biomass and Soils}

Carbon sequestration in mangrove woody biomass and soils were estimated based on a comprehensive literature review performed online on Google Scholar, Science Direct, Web of Science, and the Brazilian SciELO databases. For carbon sequestration in woody biomass, we performed searches using the following expressions: "carbon sequestration," "carbon accumulation," "wood production," "biomass production," "stem growth," "basal area increment," and "DBH increment" always in combination with the terms "mangrove" and "Brazil." Altogether the searches returned a total of 1,000 articles (Google Scholar $=815$, Science Direct $=51$, and Web of Science $=134$ ). For carbon sequestration in mangrove soils, we used the expressions "carbon sequestration," "carbon accumulation," "carbon burial," and "carbon accretion" again always in combination with the terms "mangrove" and "Brazil." Initial searches returned a total of 3,725 articles (Google Scholar $=3,240$, Science Direct $=404$, and Web of Science $=81$ ). Searches performed at the Brazilian SciELO database included generic Portuguese terms "carbono" (for carbon) and "mangue*” (for mangrove or mangal), which returned a total of 19 studies. Only studies conducted in Brazilian mangroves that presented data on carbon sequestration in either woody $\operatorname{AGB}(N=2)$ or soils $(N=7)$ were included in our analyses. Carbon sequestration rates in mangrove woody biomass and soils were classified into one of four coastal geomorphic types along Brazil's shoreline: deltas, estuaries, lagoons or open coasts (after Worthington et al., 2020b). Differences among those coastal typologies were assessed using analysis of variance for unbalanced designs (ANOVA function from R "car" package; Fox and Weisberg, 2019).

\section{Carbon Dioxide Equivalents Emissions and Foregone Carbon Sequestration}

Carbon dioxide equivalents $\left(\mathrm{CO}_{2 e q}\right)$ for both carbon stock and carbon sequestration rate values were estimated using a $\mathrm{CO}_{2}: \mathrm{C}$ stoichiometric ratio of 3.67 (i.e., $\mathrm{CO}_{2} / \mathrm{C}=44 / 12=3.67$ ), which is used as a multiplying factor to convert carbon atoms to $\mathrm{CO}_{2}$ molecules. Potential $\mathrm{CO}_{2 \mathrm{eq}}$ emissions were computed on a "stock-difference" basis (sensu Kauffman et al., 2017) using published mangrove biomass and soil carbon stock estimates (based on Rovai et al., 2018, 2021b as detailed above) and carbon sequestration rates (from the literature review). Further, we coupled degradation-specific carbon emission factors (after 
Sasmito et al., 2019: Erosion AGB $=1$, SOC $=1$; Clearing $\mathrm{AGB}=0.7, \mathrm{SOC}=0.21$; Settlement $\mathrm{AGB}=1, \mathrm{SOC}=0.66$; Extreme weather $\mathrm{AGB}=0.31, \mathrm{SOC}=0.14$; Agriculture and aquaculture $\mathrm{AGB}=0.83$, $\mathrm{SOC}=0.52$ ) with a high-resolution map of drivers of mangrove forest loss (covering the period 20002016; after Goldberg et al., 2020) to determine the dominant historical cause of mangrove degradation for each Brazilian state. While some mangrove loss drivers may change over time, dominant degradation causes, particularly those driven by climate (e.g., erosion caused by sea level rise and extreme weather events, which affects $85 \%$ of the country's mangrove coverage; Goldberg et al., 2020), are likely to remain as a result of global climate change. Likewise, agriculture or aquaculture and clearing may be harder to reduce in Brazil in the years to come due to increasing relaxation of environmental regulations. Once determined, dominant state-level emission factors were multiplied by carbon stocks in AGB and in soils (top 1 meter) separately and then summed to compute ecosystem-level potential $\mathrm{CO}_{2 \text { eq }}$ emissions for each mangrove cell in the gridded dataset (that is, AGB and SOC density estimates combined from Rovai et al., 2018, 2021b).

All raster and vector manipulations and geospatial analyses were performed using R (R Core Team, 2020) packages 'geobr' (Pereira and Goncalves, 2021), 'raster' (Hijmans, 2020), and 'rgdal' (Bivand et al., 2020).

\section{RESULTS AND DISCUSSION}

\section{Carbon Stocks in Biomass and Soils}

Based on recent global estimates (Table 1), Brazil holds on average $8.5 \%$ (or $0.32 \mathrm{PgC}$ ) of the world's mangrove organic carbon stocks, partitioned among AGB (0.05 PgC or $6.9 \%$ of global stocks), BGB (0.02 PgC or $6.1 \%$ of global stocks) and soils $(0.21 \mathrm{PgC}$ or $7.0 \%$ of global stocks). On a per-area basis, Brazilian mangroves store on average 66, 33, and $241 \mathrm{MgC} \mathrm{ha}^{-1}$ in AGB, BGB and soils, respectively (from Rovai et al., 2018, $2021 \mathrm{~b}$ for AGB and BGB, and SOC, respectively). Standardized to the same mangrove forest coverage, these values are comparable to and often more conservative than other studies' estimates. However, our ecosystem-level carbon stock estimate for Brazilian mangroves is $36 \%$ lower than that reported in Hamilton and Friess (2018) due to overestimated SOC density estimates for Brazil (from Jardine and Siikamäki, 2014) used in that study.

Over $80 \%$ of all mangrove carbon stocks in Brazil are found in the states of Maranhão (91.3 TgC), Pará (61.2 TgC) and Amapá (47.3 TgC), reflecting extensive coverage which amounts to more than $80 \%$ of the country's total mangrove area (Table 2).

Largest per-area AGB values are also found in these three states $\left(215.5,205.3\right.$, and $166.7 \mathrm{Mg} \mathrm{ha}^{-1}$ in Amapá, Pará and Maranhão, respectively) as well as in Piauí (143.4 $\mathrm{Mg} \mathrm{ha}^{-1}$ ), where mangroves develop in nutrient-rich deltaic systems. In contrast, lowest per-area AGB was found in Santa Catarina (56.8 $\mathrm{Mg} \mathrm{ha}^{-1}$ ), near the austral distribution limit for mangrove forests in the Southwestern Atlantic (Schaeffer-Novelli et al., 1990; Soares et al., 2012). AGB was also lower in São Paulo (84.2 $\mathrm{Mg} \mathrm{ha}^{-1}$ ) and Rio de Janeiro (83.1 $\mathrm{Mg} \mathrm{ha}^{-1}$ ), where extensive mangrove areas have been impacted by industrial activities and urban expansion (Soares, 1999; Ferreira and Lacerda, 2016; Moschetto et al., 2021). AGB values $<100 \mathrm{Mg} \mathrm{ha}^{-1}$ were also found in Paraíba, Sergipe, Pernambuco, Ceará and Alagoas where shrimp farming has compromised the structural and functional integrity of Brazil's drier-climate mangrove forests (Lacerda et al., 2021). AGB values $>100 \mathrm{Mg} \mathrm{ha}^{-1}$ were found in Espírito Santo and Bahia mangroves where the multidecadal stability of more than $70 \%$ of the mangrove coverage suggests that the integrity of

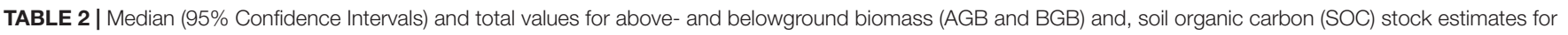
Brazilian states.

\begin{tabular}{|c|c|c|c|c|c|c|c|c|}
\hline State & $\begin{array}{l}\text { Mangrove } \\
\text { area (ha) }\end{array}$ & $\begin{array}{c}\text { AGB } \\
\left(\mathrm{Mg} \mathrm{ha}^{-1}\right)\end{array}$ & $\begin{array}{c}\text { SOC } \\
\left(\mathrm{Mg} \mathrm{ha}^{-1}\right)\end{array}$ & $\begin{array}{c}\text { Total OC in } \\
\text { AGB (Tg) }\end{array}$ & $\begin{array}{l}\text { Total OC in } \\
\text { BGB }(\mathrm{Tg})^{\mathrm{b}}\end{array}$ & $\begin{array}{c}\text { Total SOC } \\
\text { (Tg) }\end{array}$ & $\begin{array}{c}\text { Ecosystem-level } \\
\text { C (Tg) }\end{array}$ & $\begin{array}{c}\text { Ecosystem-level } \\
\text { C (\%) }\end{array}$ \\
\hline Maranhão (MA) & $297,158.47$ & $167(160-171)$ & $178(174-179)$ & 24.74 & 12.37 & 54.15 & 91.26 & 36.56 \\
\hline Pará (PA) & $186,977.44$ & 205 (200-208) & 196 (173-209) & 18.17 & 9.08 & 33.94 & 61.19 & 24.52 \\
\hline Amapá (AP) & $141,625.98$ & $215(200-227)$ & 209 (138-209) & 14.26 & 7.13 & 25.92 & 47.31 & 18.95 \\
\hline Bahia (BA) & $46,460.39$ & $106(90-114)$ & 278 (276-279) & 2.53 & 1.27 & 12.90 & 16.70 & 6.69 \\
\hline Paraná (PR) & $19,581.39$ & $99(92-108)$ & 269 (260-269) & 0.97 & 0.48 & 5.26 & 6.71 & 2.69 \\
\hline São Paulo (SP) & $14,776.24$ & 84 (76-88) & 270 (269-272) & 0.60 & 0.30 & 4.07 & 4.97 & 1.99 \\
\hline Sergipe (SE) & $10,056.71$ & $98(87-121)$ & 286 (283-286) & 0.53 & 0.26 & 2.90 & 3.69 & 1.48 \\
\hline Pernambuco (PE) & $8,821.82$ & $99(93-121)$ & 281 (276-281) & 0.44 & 0.22 & 2.47 & 3.13 & 1.25 \\
\hline Paraíba (PB) & $8,579.79$ & $80(75-84)$ & 269 (268-269) & 0.33 & 0.16 & 2.33 & 2.82 & 1.13 \\
\hline Rio de Janeiro (RJ) & $7,182.39$ & $83(77-87)$ & 293 (289-306) & 0.35 & 0.17 & 2.21 & 2.73 & 1.09 \\
\hline Santa Catarina (SC) & $6,430.90$ & 57 (44-66) & 285 (279-297) & 0.21 & 0.10 & 1.82 & 2.14 & 0.86 \\
\hline Espírito Santo (ES) & $5,796.23$ & $119(102-128)$ & $292(256-304)$ & 0.29 & 0.14 & 1.68 & 2.11 & 0.85 \\
\hline Rio Grande do Norte (RN) & $5,012.71$ & $102(93-105)$ & 272 (268-272) & 0.27 & 0.13 & 1.37 & 1.77 & 0.71 \\
\hline Ceará (CE) & $3,532.48$ & 79 (74-93) & $253(247-253)$ & 0.16 & 0.08 & 0.89 & 1.14 & 0.46 \\
\hline Alagoas (AL) & $2,826.20$ & $97(88-106)$ & $284(281-285)$ & 0.13 & 0.06 & 0.81 & 1.00 & 0.40 \\
\hline \multirow[t]{2}{*}{ Piauí (PI) } & $2,680.41$ & $144(80-182)$ & 239 (237-239) & 0.18 & 0.09 & 0.65 & 0.92 & 0.37 \\
\hline & Total & & & 64.14 & 32.07 & 153.37 & 249.58 & 100 \\
\hline
\end{tabular}

astimated using Hamilton and Casey (2016) mangrove cover dataset.

${ }^{b}$ Estimated using Hamilton and Friess (2018) 0.5 AGB to BGB conversion factor. OC, organic carbon. 


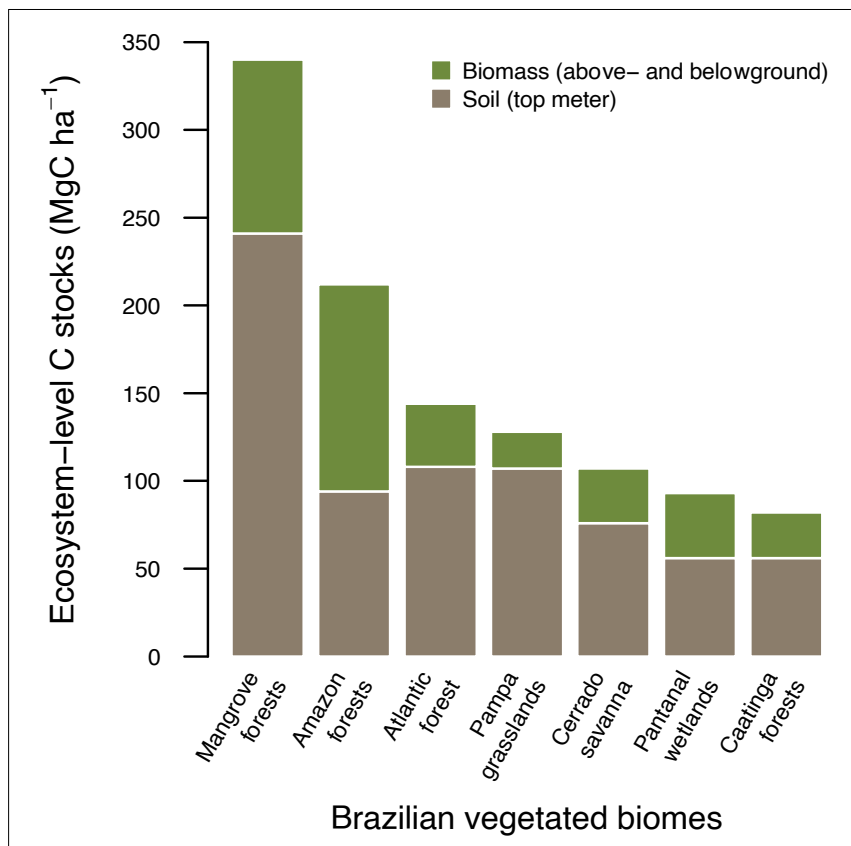

FIGURE 1 | Comparison of ecosystem-level carbon stocks (above-, belowground biomass and soil organic carbon in the top 1 meter combined) among major Brazilian vegetated biomes.

core areas have been maintained over time (Diniz et al., 2019). Predicted median AGB for Rio Grande do Norte mangroves was also $>100 \mathrm{Mg} \mathrm{ha}^{-1}$ despite mangroves developing in a semiarid climate and historical damage from shrimp farming (Lacerda et al., 2021). However, this result is likely due to the small number of observations used to constrain biomass predictions for that region (only two AGB values available for Rio Grande do Norte at the time Rovai et al., 2021b study was conducted; Supplementary Table 1). Regarding SOC stocks, deltaic mangroves in Piauí, Amapá, Pará and Maranhão states had lower soil carbon density due to higher inorganic-to-organic ratio per soil volume characteristic of coastal deltaic floodplains when compared to predominantly estuarine or lagoonal mangroves (Rovai et al., 2018; Sanderman et al., 2018; Jennerjahn, 2020; MacKenzie et al., 2020) found in other Brazilian states (Table 2). When summed, carbon stocks in biomass (AGB+BGB) and soils across Brazilian mangroves averaged $341 \mathrm{MgC} \mathrm{ha}^{-1}$ (range: 297-397 $\mathrm{MgC} \mathrm{ha}{ }^{-1}$ ), showing little variation among states (e.g., maximum difference of $23 \%$ or $\sim 80 \mathrm{MgC} \mathrm{ha}^{-1}$ ) (Table 2). This relatively small variability in per-unit area carbon stocks reflect mangrove plants' resource partitioning strategies in response to broad geographical gradients (Rovai et al., 2021b), chiefly the role of coastal geomorphology in controlling the ratio between inorganic and organic matter in mangrove soils (Twilley et al., 2018; Jennerjahn, 2020).

Comparatively, on a per-area basis mangroves store between 2.2 and 4.3 times more carbon in the top meter of soil relative to other Brazilian vegetated biomes (Figure 1). Regarding mean carbon stocks in biomass (AGB and BGB combined), mangroves are second only to the Amazon forest, and 2.7-4.7 times higher than other Brazilian vegetation formations.

\section{Carbon Sequestration in AGB and Soils}

Currently, only two studies in Brazil report on carbon sequestration in mangrove woody AGB (Table 3). From these studies, carbon sequestration in Brazilian mangroves' woody AGB was estimated at $3.18 \mathrm{MgC} \mathrm{ha}^{-1} \mathrm{yr}^{-1}$, consistent with values reported for a diversity of coastal typologies worldwide (Table 3). Thus, we used this reference value to produce a first order country-level estimate of annual carbon sequestration in Brazilian mangrove AGB, which totals $2.44{\mathrm{TgC} \mathrm{yr}^{-1}}^{-1}$, equivalent to $10 \%$ of all carbon sequestered in mangroves AGB globally.

Long-term carbon sequestration rates (mostly ${ }^{210} \mathrm{~Pb}$-dated cores) in Brazilian mangrove soils was estimated at 2.81 $\mathrm{MgC} \mathrm{ha} \mathrm{yr}^{-1}$ (Table 4). While there were no differences $(P>0.05$, results not shown) across the coastal geomorphic types found along Brazil's shoreline, this value is $15-30 \%$ higher than recent global estimates (e.g,. 1.94-2.39 $\mathrm{MgC} \mathrm{ha}^{-1} \mathrm{yr}^{-1}$; Jennerjahn, 2020; MacKenzie et al., 2020; Wang et al., 2020), likely due to the predominance of minerogenic coastlines (deltaic, which accounts for $>80 \%$ of the country's mangrove area, and meso- and macrotidal estuarine systems) where deposition of both autochthonous (mangrove detritus) and allochthonous (terrestrial and marine detritus) sediments are amplified (Adame et al., 2010; Kusumaningtyas et al., 2019; Cragg et al., 2020). Importantly, when this national median value is multiplied by the country's mangrove area coverage, annual carbon sequestration in Brazilian mangroves soils was estimated at 2.14 $\mathrm{TgC}_{\mathrm{yr}}^{-1}$, corresponding to about $13.5 \%$ of the total amount of carbon buried annually in the world's mangroves.

\section{Potential $\mathrm{CO}_{2 \text { eq }}$ Emissions and Foregone Carbon Sequestration}

Highest potential $\mathrm{CO}_{2 \mathrm{eq}}$ emissions ( $>900 \quad \mathrm{MgCO}_{2 \mathrm{eq}} \mathrm{ha}^{-1}$ ) resulting from loss of existing mangrove forests were estimated for Rio de Janeiro, Alagoas, Piauí, Pará, Amapá, and Maranhão states driven by the dominance of erosion (Figure 2 and Table 5) where eventually all carbon stored in soils (here based on top 1 meter) and in AGB is lost to the atmosphere. It should be noted, however, that while eroded SOC is rapidly mineralized in aerobic estuarine waters (Sapkota and White, 2021), carbon release back to the atmosphere from biomass loss is not immediate given slow decomposition rates of downed wood in mangrove forests (Romero et al., 2005). Notably, when considering only the top 1 meter of soil to compute such estimates, these values are amongst the highest $\mathrm{CO}_{2 \mathrm{eq}}$ emissions reported in the literature for other mangrove sites worldwide (Kauffman et al., 2017; Alongi, 2020; Adame et al., 2021). Further agriculture/aquaculture- and settlement-based losses (emission factors of 0.83 and 1.00 for AGB and 0.52 and 0.66 for SOC, respectively) were also anticipated to cause high potential $\mathrm{CO}_{2 \mathrm{eq}}$ emissions (>500 $\mathrm{MgCO}_{2 \mathrm{eq}} \mathrm{ha}^{-1}$ ) in Espírito Santo, Pernambuco, Rio Grande do Norte, São Paulo, and Santa Catarina states as these activities represent a considerable loss of both aboveground and soil compartments (Figure 2). 
TABLE 3 | Carbon sequestration rates in woody biomass for Brazilian and global mangroves.

\begin{tabular}{|c|c|c|c|c|}
\hline Region & State & Typology & Wood NPP (MgC ha-1 $\left.\mathrm{yr}^{-1}\right)$ & Source \\
\hline \multirow[t]{7}{*}{ Southeast } & Rio de Janeiro (RJ) & Open coast & $2.64 \pm 1.03$ & Estrada et al., $2015^{a}$ \\
\hline & & & $1.90 \pm 1.00$ & \\
\hline & & & $2.39 \pm 1.45$ & \\
\hline & São Paulo (SP) & Lagoon & $7.03 \pm 1.30$ & Data from Rovai et al., 2021a \\
\hline & & & $4.06 \pm 1.16$ & \\
\hline & & & $3.71 \pm 1.07$ & \\
\hline & Overall median $(95 \%$ Confi & Brazil & $3.18(2.14-4.84)$ & \\
\hline \multirow[t]{5}{*}{ Global } & & Deltas & $3.64 \pm 0.30$ & Data from Xiong et al., $2019^{b}$ \\
\hline & & Estuaries & $2.96 \pm 0.39$ & \\
\hline & & Lagoons & $4.64 \pm 1.32$ & \\
\hline & & Open coasts & $4.14 \pm 0.63$ & \\
\hline & \multicolumn{2}{|c|}{ Overall median (95\% Confidence Intervals) global } & 3.89 (2.96-4.39) & \\
\hline
\end{tabular}

${ }^{a}$ Mean $\pm 1 S D$ as reported in the original study.

${ }^{b}$ Mean $\pm 1 S E$.

NPP, net primary productivity.

TABLE 4 | Carbon sequestration rates in soils for Brazilian mangroves.

\begin{tabular}{|c|c|c|c|c|c|c|}
\hline Region & State & Site & Typology & $\begin{array}{c}\text { Carbon } \\
\text { sequestration rate } \\
\left(\mathrm{MgC} \mathrm{ha}^{-1} \mathrm{yr}^{-1}\right)\end{array}$ & Dating method & Source \\
\hline North & Pará (PA) & Ajuruteua & Delta & 2.54 & & Wang et al., 2020 \\
\hline \multirow[t]{7}{*}{ Northeast } & Pernambuco (PE) & Tamandaré & Estuary & 3.53 & $210 \mathrm{~Pb}$ & Sanders et al., 2010b \\
\hline & & Tamandaré & Estuary & 9.49 & $210 \mathrm{~Pb}$ & Sanders et al., 2010b \\
\hline & Bahia (BA) & Jaguaripe & Estuary & $1.26 \pm 0.14^{a}$ & $210 \mathrm{~Pb}$ & Hatje et al., 2021 \\
\hline & & Jaguaripe & Estuary & $1.28 \pm 0.03^{a}$ & $210 \mathrm{~Pb}$ & Hatje et al., 2021 \\
\hline & & Jaguaripe & Estuary & $2.89 \pm 0.09^{a}$ & $210 \mathrm{~Pb}$ & Hatje et al., 2021 \\
\hline & & Jaguaripe & Estuary & $3.37 \pm 0.07^{a}$ & $210 \mathrm{~Pb}$ & Hatje et al., 2021 \\
\hline & & Jaguaripe & Estuary & $4.08 \pm 0.04^{a}$ & $210 \mathrm{~Pb}$ & Hatje et al., 2021 \\
\hline ‘ & & Jaguaripe & Estuary & $7.76 \pm 1.28^{a}$ & $210 \mathrm{~Pb}$ & Hatje et al., 2021 \\
\hline \multirow[t]{12}{*}{ Southeast } & Espírito Santo (ES) & Caieira Velha & Estuary & 2.82 & & Wang et al., 2020 \\
\hline & & Vitoria & Estuary & 3.79 & & Wang et al., 2020 \\
\hline & & Anchieta & Open coast & 4.30 & $210 \mathrm{~Pb}$ & Wang et al., 2020 \\
\hline & Rio de Janeiro (RJ) & Ilha Grande & Open coast & 1.86 & $210 \mathrm{~Pb}$ & Sanders et al., 2008 \\
\hline & & Ilha Grande & Open coast & 1.69 & $210 \mathrm{~Pb}$ & Sanders et al., 2010c \\
\hline & & Guanabara & Estuary & 2.76 & & Wang et al., 2020 \\
\hline & & Guanabara & Estuary & 2.93 & & Wang et al., 2020 \\
\hline & & Sepetiba & Open coast & 5.85 & & Wang et al., 2020 \\
\hline & São Paulo (SP) & Cananéia & Lagoon & $2.80 \pm 0.14^{b}$ & $137 \mathrm{Cs}$ & Sanders et al., 2014 \\
\hline & & Cubatão & Lagoon & $10.21 \pm 0.93^{\mathrm{b}, \mathrm{c}}$ & $137 \mathrm{Cs}$ & Sanders et al., 2014 \\
\hline & & Cananéia & Lagoon & 1.92 & $210 \mathrm{~Pb}$ & Sanders et al., 2010a \\
\hline & & Cananéia & Lagoon & 2.34 & $210 \mathrm{~Pb}$ & Sanders et al., 2010a \\
\hline \multirow[t]{3}{*}{ South } & Paraná (PR) & Paranaguá & Estuary & 1.68 & $210 \mathrm{~Pb}$ & Sanders et al., 2010c \\
\hline & & Guaratuba & Estuary & 3.37 & $210 \mathrm{~Pb}$ & Sanders et al., 2010c \\
\hline & Overall median (95 & onfidence Inte & & $2.81(1.92-3.37)$ & & \\
\hline
\end{tabular}

${ }^{a}$ Mean $\pm 1 S E$ computed from different depths within same cores for each site.

${ }^{b}$ Mean $\pm 1 S E$ computed from two sites.

cImpacted site, not used to compute median and 95\% Cl's.

Lowest potential $\mathrm{CO}_{2 \mathrm{eq}}$ emissions were linked to episodic extreme weather events that have the potential to release smaller fractions on carbon stored in AGB (31\%) and soils (14\%) followed by clearing, which can remove substantial carbon stocks in aboveground $(70 \%)$ and soil (21\%) compartments. These estimates are conservative considering only carbon stored in AGB and soils (but not in BGB, since emission factors for this plant compartment have not been established yet) were used to compute potential $\mathrm{CO}_{2 \mathrm{eq}}$ emissions resulting from mangrove forest loss. 


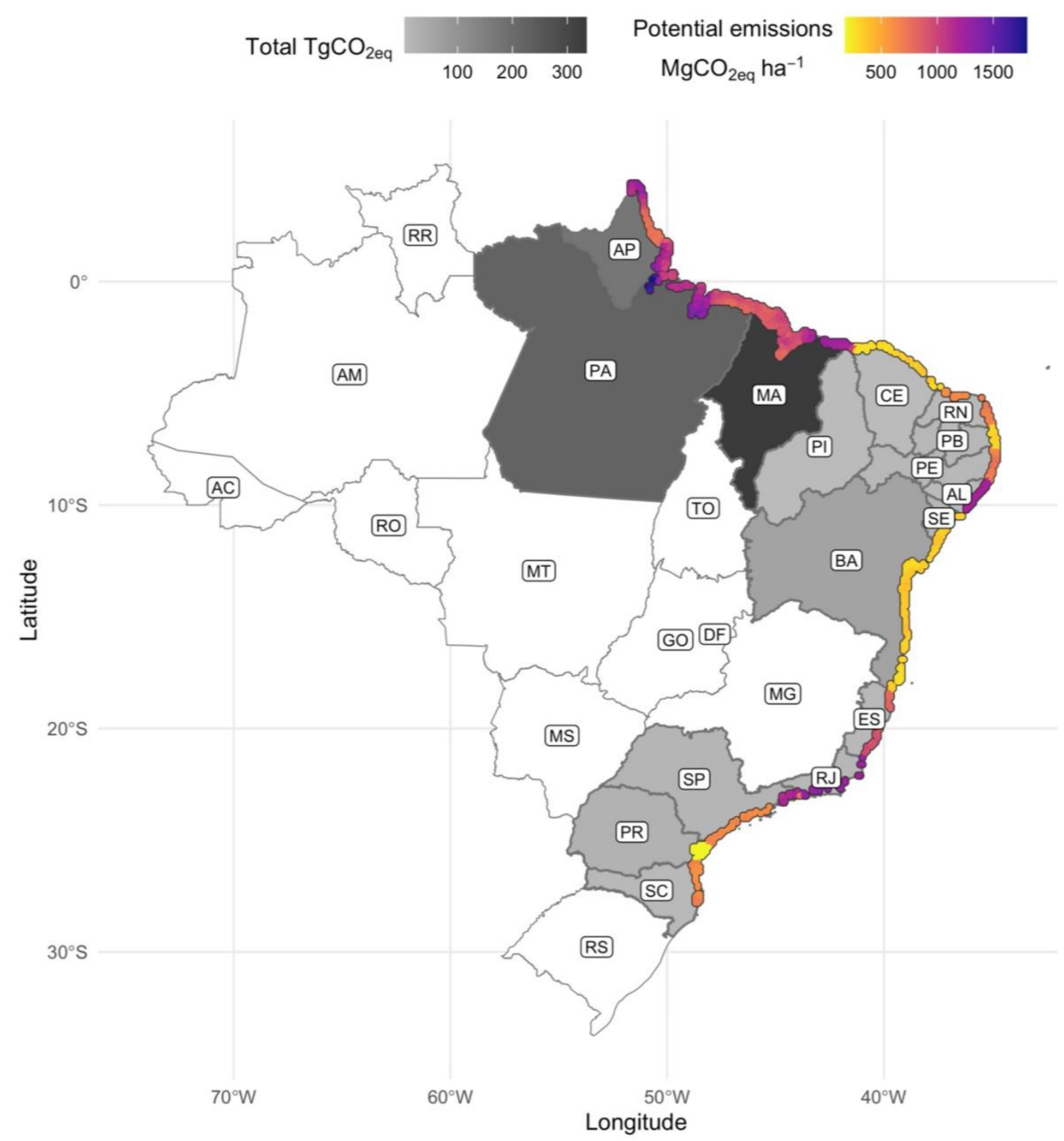

FIGURE 2 | Total $\mathrm{CO}_{2 \text { eq }}$ stored in biomass and soils (grayscale top left legend) and variability in potential $\mathrm{CO}_{2}$ eq emissions (colored scale top right legend) across Brazilian mangroves. Mangrove coverage exaggerated to improve visualization. Estimates per state are given on Table 5. Mangrove states: AP, Amapá; PA, Pará; MA, Maranhão; PI, Piauí; CE, Ceará; RN, Rio Grande do Norte; PB, Paraíba; PE, Pernambuco; AL, Alagoas; SE, Sergipe; BA, Bahia; ES, Espírito Santo; RJ, Rio de Janeiro; SP, São Paulo; PR, Paraná; and SC, Santa Catarina. Non-mangrove states: RR, Roraima; AM, Amazonas; AC, Acre; RO, Rondônia; MT, Mato Grosso; TO, Tocantins; GO, Goiás; DF, Distrito Federal; MS, Mato Grosso do Sul; MG, Minas Gerais; RS, Rio Grande do Sul.

The loss of carbon sequestration potential after mangrove forests are degraded was assumed here to be $100 \%$ considering that soil and vegetation loss represent either acute stressors, which ceases mangrove production altogether, or chronic stressors that leave the system more susceptible to eventually collapse (Lugo et al., 1981; Lewis et al., 2016; Krauss et al., 2018). Further, there are currently no consistent degradation-specific emission factors available to estimate loss of carbon sequestration potential as there is for change in carbon stocks resulting from distinct mangrove deforestation causes (e.g., Sasmito et al., 2019).
Based on the current reference value of $2.81 \mathrm{MgC} \mathrm{ha}^{-1}$ $\mathrm{yr}^{-1}$ (Table 4), we estimated an annual loss of 10.31 $\mathrm{MgCO}_{2} \mathrm{ha}^{-1} \mathrm{yr}^{-1}$ that would otherwise be buried in mangrove soils. Combined with loss of carbon sequestration potential in woody biomass, based on the current reference value of $3.18 \mathrm{MgC} \mathrm{ha}^{-1} \mathrm{yr}^{-1}$ (Table 3), foregone carbon sequestration in Brazilian mangroves annually could total 22 $\mathrm{MgCO}_{2} \mathrm{ha}^{-1} \mathrm{yr}^{-1}$, in line with estimates reported for other mangroves worldwide (23-254 $\mathrm{MgCO}_{2} \mathrm{ha}^{-1} \mathrm{yr}^{-1}$ as reviewed in Alongi, 2014). 
TABLE 5 | Median values (95\% Confidence Intervals) for potential $\mathrm{CO}_{2 \mathrm{eq}}$ emissions resulting from mangrove forest loss across Brazil.

\begin{tabular}{|c|c|c|c|c|}
\hline State & $\begin{array}{l}\text { Dominant driver of } \\
\text { mangrove loss }\end{array}$ & $\begin{array}{c}\text { Potential emissions } \\
\text { AGB } \\
\left(\mathrm{MgCO}_{2 \mathrm{eq}} \mathrm{ha}^{-1}\right)\end{array}$ & $\begin{array}{l}\text { Potential emissions } \\
\text { SOC } \\
\left(\mathrm{MgCO}_{2 \mathrm{eq}} \mathrm{ha}^{-1}\right)\end{array}$ & $\begin{array}{l}\text { Potential emissions } \\
\text { Ecosystem-level } \\
\left(\mathrm{MgCO}_{2 \mathrm{eq}} \mathrm{ha}^{-1}\right)\end{array}$ \\
\hline Alagoas (AL) & Erosion & $169(154-185)$ & $1,040(1,030-1,050)$ & $1,210(1,190-1,220)$ \\
\hline Amapá (AP) & Erosion & $376(348-397)$ & $767(508-768)$ & $1,030(911-1,110)$ \\
\hline Bahia (BA) & Clearing & $130(109-139)$ & $214(212-215)$ & 341 (326-350) \\
\hline Ceará (CE) & Clearing & $97(91-113)$ & $195(186-195)$ & $288(283-315)$ \\
\hline Espírito Santo (ES) & Settlement & $208(180-223)$ & 707 (620-736) & 885 (832-921) \\
\hline Maranhão (MA) & Erosion & 291 (279-298) & $655(639-657)$ & 937 (919-957) \\
\hline Pará (PA) & Erosion & 358 (349-363) & 719 (633-767) & $1,080(1,010-1,110)$ \\
\hline Paraíba (PB) & Clearing & $97(92-102)$ & 207 (206-207) & 307 (299-309) \\
\hline Paraná (PR) & Extreme weather & $53(49-58)$ & $138(134-138)$ & $193(189-195)$ \\
\hline Pernambuco (PE) & Agri/Aquiculture & $143(135-176)$ & $536(527-536)$ & $677(657-713)$ \\
\hline Piauí (PI) & Erosion & $251(140-316)$ & $877(871-877)$ & $1,120(1,010-1,190)$ \\
\hline Rio de Janeiro (RJ) & Erosion & 145 (134-152) & $1,070(1,060-1,120)$ & $1,250(1,200-1,260)$ \\
\hline Rio Grande do Norte (RN) & Agri/Aquiculture & $148(134-153)$ & $519(511-519)$ & $667(651-672)$ \\
\hline Santa Catarina (SC) & Agri/Aquiculture & 82 (64-95.) & $545(533-556)$ & 620 (612-655) \\
\hline São Paulo (SP) & Agri/Aquiculture & $122(111-128)$ & $516(513-519)$ & 645 (625-649) \\
\hline Sergipe (SE) & Clearing & $120(106-148)$ & $220(218-220)$ & 340 (327-373) \\
\hline Total & & 2,791 & 8,925 & 11,590 \\
\hline
\end{tabular}

aAfter Goldberg et al. (2020). See "Materials and Methods" section for details about emission factors applied to estimate CO 2 eq emissions for each of these categories. $A G B$, aboveground biomass; SOC, soil organic carbon.

\section{CONCLUSION AND RECOMMENDATIONS}

Here we deliver the first integrated assessment of mangrove carbon stocks, carbon sequestration rates and potential $\mathrm{CO}_{2 \mathrm{eq}}$ emissions for each Brazilian state. While more data are needed (e.g., particularly on carbon sequestration and emission factors) to better quantify national level statistics, this study provides compelling information to both aid the inclusion of mangroves in national (or state-level) carbon credit markets and establish Brazilian mangroves as hotspots within the context of global blue carbon policies. Our estimates suggest that Brazilian mangroves can potentially release substantial amounts of carbon following mangrove forest loss, with $\mathrm{CO}_{2 \mathrm{eq}}$ emissions nearing those estimated for other carbon-rich mangrove forests. In addition, loss of carbon sequestration potential in both woody biomass and soils following deforestation amplifies cumulative emissions annually, shortening the country's capacity to mitigate its fossil fuel emissions and meet intended NDC's.

In summary, we showed that Brazil is home of $9.3 \%$ of the world's mangroves, commensurably holding $8.5 \%$ of the global mangrove carbon stocks (biomass and soils combined). When compared to other Brazilian vegetated biomes, on a per-area basis mangroves store between 2.2 and 4.3 times more carbon in the top meter of soil. While for carbon stocks in biomass, Brazilian mangroves are second only to the Amazon forest, and store between 2.7 and 4.7 times more carbon than other vegetated biomes. Moreover, on a per-area basis organic carbon sequestration rates in Brazilian mangroves are 15-30\% higher than recent global estimates. Importantly, integrated over the country's area, carbon sequestration in Brazilian mangroves soils account for $13.6 \%$ of the carbon buried in world's mangroves annually. Likewise, carbon sequestration in Brazilian mangroves woody biomass is also higher than global estimates, accounting for nearly $10 \%$ of carbon accumulation in mangrove woody biomass globally.

This study also highlights important research gaps and uncertainties in Brazilian mangroves carbon inventories. For example, the greatest carbon sink capacity in mangroves lies in the soils since this ecosystem compartment continuously fixes and preserves layers of millennia-old atmospheric carbon beneath the surface. However, we still know very little about the carbon sequestration potential of Brazilian mangroves soils, particularly the contribution of the Amazon Macrotidal Mangrove Coast (AMMC) to global carbon budgets. To date, we have found only one study reporting on soil carbon sequestration rates in this region (Table 4). Overall, several of Brazil's northern and northeastern states, where $>80 \%$ of the country's mangroves are present, lack data; seven and nine states out of the 16 mangrove states in Brazil still lack data on soil organic carbon stocks and sequestration rates, respectively (Supplementary Table 1). It should also be noted that, while this study focused on carbon stocks and long-term carbon sequestration rates in biomass and soils, real time air-sea $\mathrm{CO}_{2}$ fluxes, and $\mathrm{DOC}$ (dissolved organic carbon), DIC (dissolved inorganic carbon), and alkalinity (bicarbonate) export are important mechanisms of the carbon cycling in mangroves (e.g., Sippo et al., 2016; Carvalho et al., 2017; Cotovicz et al., 2019; Cabral et al., 2021) and should be taken into account to better constrain carbon budgets for Brazilian mangroves.

Mangrove AGB density has been consistently mapped across Brazilian mangroves, but disparities exist. For instance, no data 
was apparent for Alagoas' mangroves and only a few plots have been implemented in Amapá (2 plots), Piauí (2 plots), Rio Grande do Norte (2 plots), and Paraíba (6 plots) states (Supplementary Table 1). While for carbon sequestration in woody biomass, currently only two states (Rio de Janeiro and São Paulo) are represented (Table 3). The situation is far more critical for BGB density and productivity estimates. In this study we used a 0.5 $\mathrm{BGB}$ :AGB ratio to estimate BGB across Brazilian mangroves; however, to our knowledge, there are only two studies that have comprehensively (using trenching vs. coring techniques; see Adame et al., 2017 for a comprehensive discussion) assessed actual BGB distribution in Brazilian mangroves (Santos et al., 2017 in Rio de Janeiro and Virgulino-Júnior et al., 2020 in Pará). Moreover, BGB productivity and root necromass, which are important contributors to refractory carbon stored in mangroves soils (Kihara et al., 2021), remain unknown for Brazilian mangroves.

It is imperative that future research efforts and funding opportunities focus on addressing these data coverage issues. This is particularly pertinent for the data-poor northern states, where the AMMC is located, as carbon fluxes are more intense due to the synergistic contribution or riverine and tidal forcings that dictate coastal and ecological processes (e.g., deposition, erosion, mineralization, export). We recommend future carbon inventories in Brazilian mangroves to look beyond carbon stocks in biomass and soils and prioritize carbon fluxes via biomass (e.g., woody biomass growth) and soils (long-term carbon sequestration) as well as export of other carbon forms (e.g., DOC, DIC, alkalinity), which provide a direct comparison to greenhouse gases emission rates. Overall, this study consolidates the scientific basis demonstrating the significance of Brazilian mangroves to achieve NDC's both by enforcing environmental regulations to protect the country's existing mangroves and by promoting

\section{REFERENCES}

Adame, M. F., Cherian, S., Reef, R., and Stewart-Koster, B. (2017). Mangrove root biomass and the uncertainty of belowground carbon estimations. For. Ecol. Manage. 403, 52-60. doi: 10.1016/j.foreco.2017.08.016

Adame, M. F., Connolly, R. M., Turschwell, M. P., Lovelock, C. E., Fatoyinbo, T., Lagomasino, D., et al. (2021). Future carbon emissions from global mangrove forest loss. Glob. Chang. Biol. 27, 2856-2866. doi: 10.1111/gcb.15571

Adame, M. F., Neil, D., Wright, S. F., and Lovelock, C. E. (2010). Sedimentation within and among mangrove forests along a gradient of geomorphological settings. Estuar. Coast. Shelf Sci. 86, 21-30. doi: 10.1016/j.ecss.2009.10.013

Alongi, D. M. (2014). Carbon cycling and storage in mangrove forests. Ann. Rev. Mar. Sci. 6, 195-219. doi: 10.1146/annurev-marine-010213-135020

Alongi, D. M. (2020). Global significance of mangrove blue carbon in climate change mitigation. Science 2:67. doi: 10.3390/sci2030067

Atwood, T. B., Connolly, R. M., Almahasheer, H., Carnell, P. E., Duarte, C. M., Ewers Lewis, C. J., et al. (2017). Global patterns in mangrove soil carbon stocks and losses. Nat. Clim. Chang. 7, 523-528. doi: 10.1038/nclimate3326

Bivand, R., Keitt, T., and Rowlingson, B. (2020). R Package Rgdal: bindings For The Geospatial Data Abstraction Library. 65. Available online at: https://cran. r-project.org/web/packages/rgdal/rgdal.pdf (accessed November 30, 2021).

Bukoski, J. J., Elwin, A., MacKenzie, R. A., Sharma, S., Purbopuspito, J., Kopania, B., et al. (2020). The role of predictive model data in designing mangrove forest carbon programs. Environ. Res. Lett. 15, 084019. doi: 10.1088/1748-9326/ $\mathrm{ab} 7 \mathrm{e} 4 \mathrm{e}$ mangrove restoration where feasible to increase carbon crediting potential.

\section{DATA AVAILABILITY STATEMENT}

The original contributions presented in the study are included in the article/Supplementary Material, further inquiries can be directed to the corresponding author.

\section{AUTHOR CONTRIBUTIONS}

AR conceived the study, collated and analyzed data, and wrote the draft. RT, TW, and PR analyzed data and wrote the draft. All authors contributed to the article and approved the submitted version.

\section{ACKNOWLEDGMENTS}

AR is thankful to the Brazilian foundations CAPES and CNPq, and their Science Without Borders program for having funded the Ph.D. research (BEX1930/13-3) in which much of the data used in this study has originated. We are grateful to Jacob Bukoski for providing insightful comments that have much improved the quality of our original draft.

\section{SUPPLEMENTARY MATERIAL}

The Supplementary Material for this article can be found online at: https://www.frontiersin.org/articles/10.3389/ffgc.2021. 787533/full\#supplementary-material

Cabral, A., Dittmar, T., Call, M., Scholten, J., de Rezende, C. E., Asp, N., et al. (2021). Carbon and alkalinity outwelling across the groundwater-creek-shelf continuum off Amazonian mangroves. Limnol. Oceanogr. Lett. 6, 369-378. doi: $10.1002 / \mathrm{lol} 2.10210$

Carpenter, J., and Bithell, J. (2000). Bootstrap confidence intervals: when, which, what? A practical guide for medical statisticians. Stat. Med. 19, 1141-1164. doi: 10.1002/(SICI)1097-0258(20000515)19:9<1141::AID-SIM479>3.0.CO;2-F

Carvalho, A. C. O., Marins, R. V., Dias, F. J. S., Rezende, C. E., Lefèvre, N., Cavalcante, M. S., et al. (2017). Air-sea CO2 fluxes for the Brazilian northeast continental shelf in a climatic transition region. J. Mar. Syst. 173, 70-80. doi: 10.1016/j.jmarsys.2017.04.009

Cotovicz, L. C., Knoppers, B. A., Deirmendjian, L., and Abril, G. (2019). Sources and sinks of dissolved inorganic carbon in an urban tropical coastal bay revealed by $\delta 13$ C-DIC signals. Estuar. Coast. Shelf Sci. 220, 185-195. doi: 10.1016/j.ecss. 2019.02.048

Cragg, S. M., Friess, D. A., Gillis, L. G., Trevathan-Tackett, S. M., Terrett, O. M., Watts, J. E. M., et al. (2020). Vascular plants are globally significant contributors to marine carbon fluxes and sinks. Ann. Rev. Mar. Sci. 12, 16.1-16.29. doi: 10.1146/annurev-marine-010318-095333

Diniz, C., Cortinhas, L., Nerino, G., Rodrigues, J., Sadeck, L., Adami, M., et al. (2019). Brazilian mangrove status: Three decades of satellite data analysis. Remote Sens. 11:808. doi: 10.3390/rs11070808

Estrada, G. C. D., Soares, M. L. G., Fernadez, V., and de Almeida, P. M. M. (2015). The economic evaluation of carbon storage and sequestration as ecosystem services of mangroves: A case study from southeastern Brazil. Int. 
J. Biodivers. Sci. Ecosyst. Serv. Manag. 11, 29-35. doi: 10.1080/21513732.2014.96 3676

Ferreira, A. C., and Lacerda, L. D. (2016). Degradation and conservation of Brazilian mangroves, status and perspectives. Ocean Coast. Manag. 125, 38-46. doi: 10.1016/j.ocecoaman.2016.03.011

Fox, J., and Weisberg, S. (2019). An $\{R\}$ Companion to Applied Regression, 3rd Edn. Thousand Oaks, CA: Sage.

Gabler, C. A., Osland, M. J., Grace, J. B., Stagg, C. L., Day, R. H., Hartley, S. B., et al. (2017). Macroclimatic change expected to transform coastal wetland ecosystems this century. Nat. Clim. Chang 7, 142-147. doi: 10.1038/ NCLIMATE3203

Goldberg, L., Lagomasino, D., Thomas, N., and Fatoyinbo, T. (2020). Global declines in human-driven mangrove loss. Glob. Chang. Biol. 26, 5844-5855. doi: $10.1111 /$ gcb.15275

Hamilton, S. E., and Casey, D. (2016). Creation of a high spatio-temporal resolution global database of continuous mangrove forest cover for the 21st century (CGMFC-21). Glob. Ecol. Biogeogr. 25, 729-738. doi: 10.1111/geb.12449

Hamilton, S. E., and Friess, D. A. (2018). Global carbon stocks and potential emissions due to mangrove deforestation from 2000 to 2012. Nat. Clim. Chang. 8, 240-244. doi: 10.1038/s41558-018-0090-4

Hamilton, S. E., Castellanos-Galindo, G. A., Millones-Mayer, M., and Chen, M. (2018). "Remote sensing of mangrove forests: Current techniques and existing databases," in Threats to Mangrove Forests, eds C. Makowski and C. W. Finkl (Cham: Springer), 497-520. doi: 10.1007/978-3-319-73016-5_22

Hatje, V., Masqué, P., Patire, V. F., Dórea, A., and Barros, F. (2021). Blue carbon stocks, accumulation rates, and associated spatial variability in Brazilian mangroves. Limnol. Oceanogr. 66, 321-334. doi: 10.1002/lno.11607

Hiederer, R., and Köchy, M. (2011). Global soil organic carbon estimates and the Harmonized World 20 Soil Database, JRC Scientific and Technical Reports, 68528/EUR 25225 EN. Ispra: Joint ResearchCentre.

Hijmans, R. J. (2020). raster: Geographic Data Analysis and Modeling. R package. 249. Available online at: https://cran.r-project.org/package=raster (accessed November 30, 2021).

Holling, C. S. (1973). Resilience and stability of ecological systems. Annu. Rev. Ecol. Syst. 4, 1-23. doi: 10.1146/annurev.es.04.110173.000245

Holmquist, J. R., Windham-Myers, L., Bliss, N., Crooks, S., Morris, J. T., Megonigal, J. P., et al. (2018). Accuracy and precision of tidal wetland soil carbon mapping in the conterminous United States. Sci. Rep. 8:9478. doi: 10.1038/s41598-01826948-7

Hutchison, J., Manica, A., Swetnam, R., Balmford, A., and Spalding, M. (2014). Predicting Global Patterns in Mangrove Forest Biomass. Conserv. Lett. 7, 233-240. doi: $10.1111 /$ conl.12060

IBGE (2019). Biomas e Sistema Costeiro-Marinho do Brasil: Compatível com a escala 1:250.000 / IBGE, Coordenação de Recursos Naturais e Estudos Ambientais. Rio de Janeiro: Instituto Brasileiro de Geografia e Estatística IBGE.

IPCC (2014). 2013 Supplement to the 2006 IPCC guidelines for national greenhouse gas inventories: Wetlands. Geneva: IPCC.

Jardine, S. L., and Siikamäki, J. V. (2014). A global predictive model of carbon in mangrove soils. Environ. Res. Lett. 9:104013. doi: 10.1088/1748-9326/9/10/ 104013

Jennerjahn, T. C. (2020). Relevance and magnitude of "Blue Carbon" storage in mangrove sediments: carbon accumulation rates vs. stocks, sources vs. sinks. Estuar. Coast. Shelf Sci. 247:107027. doi: 10.1016/j.ecss.2020.107027

Kauffman, B. J., Arifanti, V. B., Hernández Trejo, H., del Carmen, Jesús García, M., Norfolk, J., et al. (2017). The jumbo carbon footprint of a shrimp: carbon losses from mangrove deforestation. Front. Ecol. Environ. 15:183-188. doi: 10.1002/ fee. 1482

Kauffman, J. B., Adame, M. F., Arifanti, V. B., Schile-Beers, L. M., Bernardino, A. F., Bhomia, R. K., et al. (2020). Total ecosystem carbon stocks of mangroves across broad global environmental and physical gradients. Ecol. Monogr. 90:e01405. doi: $10.1002 /$ ecm. 1405

Kihara, Y., Dannoura, M., and Ohashi, M. (2021). Estimation of fine root production, mortality, and decomposition by using two core methods and litterbag experiments in a mangrove forest. Ecol. Res. doi: 10.1111/1440-1703. 12275

Krauss, K. W., Demopoulos, A. W. J., Cormier, N., From, A. S., McClain-Counts, J. P., and Lewis, R. R. R. III (2018). Ghost forests of marco island: mangrove mortality driven by belowground soil structural shifts during tidal hydrologic alteration. Estuar. Coast. Shelf Sci. 212, 51-62. doi: 10.1016/j.ecss.2018.06.026

Kusumaningtyas, M. A., Hutahaean, A. A., Fischer, H. W., Pérez-Mayo, M., Ransby, D., and Jennerjahn, T. C. (2019). Variability in the organic carbon stocks, sources, and accumulation rates of Indonesian mangrove ecosystems. Estuar. Coast. Shelf Sci. 218, 310-323. doi: 10.1016/j.ecss.2018.12.007

Lacerda, L. D., Ward, R. D., Godoy, M. D. P., Meireles, A. J., de, A., Borges, R., et al. (2021). 20-Years cumulative impact from shrimp farming on mangroves of northeast brazil. Front. For. Glob. Change 4:653096. doi: 10.3389/ffgc.2021. 653096

Lewis, R. R. R., Milbrandt, E. C. E. C., Brown, B., Krauss, K. W. K. W. K. W., Rovai, A. S. A. S., Beever, J. W. J. W., et al. (2016). Stress in mangrove forests: Early detection and preemptive rehabilitation are essential for future successful worldwide mangrove forest management. Mar. Pollut. Bull. 109, 764-771. doi: 10.1016/j.marpolbul.2016.03.006

Lugo, A. E., Cintrón-Molero, G., and Goenaga, C. (1981). "Mangrove ecosystems under stress," in Stress Effects On Natural Systems, eds G. W. Barret and R. Rosenberg (Chichester: John Wiley and Sons), 129-153.

MacKenzie, R., Sharma, S., and Rovai, A. R. (2020). "Environmental drivers of blue carbon burial and soil carbon stocks in mangrove forests," in Dynamic Eedimentary Environments Of Mangrove Coasts, eds F. Sidik and D. A. Friess (Amsterdam: Elsevier Inc), 275-294. doi: 10.1016/b978-0-12-816437-2.0 0006-9

Mangiafico, S. S. (2021). Rcompanion: Functions to Support Extension Education Program Evaluation. 2.4.1. New Brunswick, NJ: Rutgers Cooperative.

McLeod, E., Chmura, G. L., Bouillon, S., Salm, R., Björk, M., Duarte, C. M., et al. (2011). A blueprint for blue carbon: toward an improved understanding of the role of vegetated coastal habitats in sequestering CO2. Front. Ecol. Environ. 9:552-560. doi: 10.1890/110004

Moschetto, F. A., Ribeiro, R. B., and De Freitas, D. M. (2021). Urban expansion, regeneration and socioenvironmental vulnerability in a mangrove ecosystem at the southeast coastal of São Paulo, Brazil. Ocean Coast. Manag. 200:105418.

Pereira, R. H. M., and Goncalves, C. N. (2021). geobr: Download Official Spatial Data Sets of Brazil, 38. Available online at: https://cran.r-project.org/web/ packages/geobr/geobr.pdf (accessed November 30, 2021).

R Core Team (2020). R: A Language And Environment For Statistical Computing. Available online at: http://www.r-project.org/ (accessed November 30, 2021).

Rogers, K., Kelleway, J. J., Saintilan, N., Megonigal, J. P., Adams, J. B., Holmquist, J. R., et al. (2019). Wetland carbon storage controlled by millennial-scale variation in relative sea-level rise. Nature 567, 91-95. doi: 10.1038/s41586-0190951-7

Romero, L. M., Smith, T. J., and Fourqurean, J. W. (2005). Changes in mass and nutrient content of wood during decomposition in a south Florida mangrove forest. J. Ecol. 93, 618-631. doi: 10.1111/j.1365-2745.2005.00970.x

Rovai, A. S., Twilley, R. R., Castañeda-Moya, E., Midway, S. R., Friess, D. A., Trettin, C. C., et al. (2021b). Macroecological patterns of forest structure and allometric scaling in mangrove forests. Glob. Ecol. Biogeogr. 30, 1000-1013. doi: 10.1111 /geb.13268

Rovai, A. S., Coelho, C., de Almeida, R., Cunha-Lignon, M., Menghini, R. P., Twilley, R. R., et al. (2021a). Ecosystem-level carbon stocks and sequestration rates in mangroves in the Cananéia-Iguape lagoon estuarine system, southeastern Brazil. For. Ecol. Manage. 479:118553. doi: 10.1016/j. foreco. 2020.118553

Rovai, A. S., Twilley, R. R., Castañeda-Moya, E., Riul, P., Cifuentes-Jara, M., Manrow-Villalobos, M., et al. (2018). Global controls on carbon storage in mangrove soils. Nat. Clim. Change 8, 534-538. doi: 10.1038/s41558-0180162-5

Saintilan, N., Khan, N. S., Ashe, E., Kelleway, J. J., Rogers, K., Woodroffe, C. D., et al. (2020). Thresholds of mangrove survival under rapid sea level rise. Science 368, 1118-1121. doi: 10.1126/science.aba2656

Sanderman, J., Hengl, T., Fiske, G., Solvik, K., Adame, M. F., Benson, L., et al. (2018). A global map of mangrove forest soil carbon at $30 \mathrm{~m}$ spatial resolution. Environ. Res. Lett. 13:055002. doi: 10.1088/1748-9326/aabe1c

Sanders, C. J., Eyre, B. D., Santos, I. R., Machado, W., Luiz-silva, W., Smoak, J. M., et al. (2014). Elevated rates of organic carbon, nitrogen, and phosphorus accumulation in a highly impacted mangrove wetland. Geophys. Res. Lett. 41, 2475-2480. doi: 10.1002/2014g1059789 
Sanders, C. J., Smoak, J. M., Naidu, A. S., and Patchineelam, S. R. (2008). Recent sediment accumulation in a mangrove forest and Its relevance to local sea-level rise (Ilha Grande, Brazil). J. Coast. Res. 24, 533-536. doi: 10.2112/07-0872.1

Sanders, C. J., Smoak, J. M., Naidu, A. S., Sanders, L. M., and Patchineelam, S. R. (2010b). Organic carbon burial in a mangrove forest, margin and intertidal mud flat. Estuar. Coast. Shelf Sci. 90, 168-172. doi: 10.1016/j.ecss.2010.08.013

Sanders, C. J., Smoak, J. M., Sanders, L. M., Sathy Naidu, A., and Patchineelam, S. R. (2010c). Organic carbon accumulation in Brazilian mangal sediments. J. South Am. Earth Sci. 30, 189-192. doi: 10.1016/j.jsames.2010.10.001

Sanders, C. J., Smoak, J. M., Naidu, A. S., Araripe, D. R., Sanders, L. M., and Patchineelam, S. R. (2010a). Mangrove forest sedimentation and its reference to sea level rise, Cananeia, Brazil. Environ. Earth Sci. 60, 1291-1301. doi: 10. 1007/s12665-009-0269-0

Santos, D. M. C., Estrada, G. C. D., Fernandez, V., Estevam, M. R. M., Souza, B. T., and Soares, M. L. G. (2017). First assessment of carbon stock in the belowground biomass of brazilian mangroves. An. Acad. Bras. Cienc. 89, 15791589. doi: 10.1590/0001-3765201720160496

Sapkota, Y., and White, J. R. (2021). Long-term fate of rapidly eroding carbon stock soil profiles in coastal wetlands. Sci. Total Environ. 753:141913. doi: 10.1016/j. scitotenv.2020.141913

Sasmito, S. D., Taillardat, P., Clendenning, J. N., Cameron, C., Friess, D. A., Murdiyarso, D., et al. (2019). Effect of land-use and land-cover change on mangrove blue carbon: a systematic review. Glob. Chang. Biol. 25, 4291-4302. doi: $10.1111 /$ gcb.14774

Schaeffer-Novelli, Y., Cintrón-Molero, G., Adaime, R. R., and Camargo, T. M. (1990). Variability of mangrove ecosystems along the Brazilian coast. Estuaries 13, 204-218. doi: 10.2307/1351590

Serrano, O., Lovelock, C. E., Atwood, T. B., Macreadie, P. I., Canto, R., Phinn, S., et al. (2019). Australian vegetated coastal ecosystems as global hotspots for climate change mitigation. Nat. Commun. 10:4313. doi: 10.1038/s41467-01912176-8

Simard, M., Fatoyinbo, L., Smetanka, C., Rivera-Monroy, V. H., Castañeda-Moya, E., Thomas, N., et al. (2019). Mangrove canopy height globally related to precipitation, temperature and cyclone frequency. Nat. Geosci. 12, 40-45. doi: 10.1038/s41561-018-0279-1

Sippo, J. Z., Maher, D. T., Tait, D. R., Holloway, C., and Santos, I. R. (2016). Are mangroves drivers or buffers of coastal acidification? Insights from alkalinity and dissolved inorganic carbon export. Glob. Biogeochem. Cycles 30, 753-766. doi: 10.1111/1462-2920.13280

Soares, M. L. G. (1999). Estrutura vegetal e grau de perturbação dos manguezais da Lagoa da Tijuca, Rio de Janeiro, RJ, Brasil. Rev. Bras. Biol. 59, 503-515. doi: 10.1590/S0034-71081999000300016

Soares, M. L. G., Estrada, G. C. D., Fernandez, V., and Tognella, M. M. P. (2012). Southern limit of the Western South Atlantic mangroves: assessment of the potential effects of global warming from a biogeographical perspective. Estuar. Coast. Shelf Sci. 101, 44-53. doi: 10.1016/j.ecss.2012.02.018

Spawn, S. A., Sullivan, C. C., Lark, T. J., and Gibbs, H. K. (2020). Harmonized global maps of above and belowground biomass carbon density in the year 2010. Sci. Data 7:112. doi: 10.1038/s41597-020-0444-4

Taillardat, P., Friess, D. A., and Lupascu, M. (2018). Mangrove blue carbon strategies for climate change mitigation are most effective at the national scale. Biol. Lett. 14:20180251. doi: 10.1098/rsbl.201 8.0251

Tang, W., Zheng, M., Zhao, X., Shi, J., Yang, J., and Trettin, C. (2018). Big geospatial data analytics for global mangrove biomass and carbon estimation. Sustainability 10:472. doi: 10.3390/su10020472

Twilley, R. R., Rovai, A. S., and Riul, P. (2018). Coastal morphology explains global blue carbon distributions. Front. Ecol. Environ. 16:503-508. doi: 10.1002/fee. 1937

Virgulino-Júnior, P. C. C., Carneiro, D. N., Nascimento, W. R., Cougo, M. F., and Fernandes, M. E. B. (2020). Biomass and carbon estimation for scrub mangrove forests and examination of their allometric associated uncertainties. PLoS One 15:e0230008. doi: 10.1371/journal.pone.0230008

Wang, F., Sanders, C. J., Santos, I. R., Tang, J., Schurech, M., Kirwan, M. L., et al. (2020). Global blue carbon accumulation in tidal wetlands increases with climate change. Natl. Sci. Rev. 8:nwaa296. doi: 10.1093/nsr/nw aa296

Worthington, T. A., Andradi-Brown, D. A., Bhargava, R., Buelow, C., Bunting, P., Duncan, C., et al. (2020a). Harnessing big data to support the conservation and rehabilitation of mangrove forests globally. One Earth 2, 429-443. doi: 10.1016/j.oneear.2020.04.018

Worthington, T. A., Ermgassen, P. S. E., Friess, D. A., Krauss, K. W., Lovelock, C. E., Thorley, J., et al. (2020b). A global biophysical typology of mangroves and its relevance for ecosystem structure and deforestation. Sci. Rep. 10:14652. doi: 10.1038/s41598-020-71194-5

Xiong, Y., Cakir, R., Phan, S. M., Ola, A., Krauss, K. W., and Lovelock, C. E. (2019). Global patterns of tree stem growth and stand aboveground wood production in mangrove forests. For. Ecol. Manage. 444, 382-392. doi: 10.1016/j.foreco.2019. 04.045

Conflict of Interest: The authors declare that the research was conducted in the absence of any commercial or financial relationships that could be construed as a potential conflict of interest.

The reviewer SC declared a past collaboration with one of the authors TW to the handling editor.

The reviewer JB declared a past co-authorship with the authors to the handling editor.

Publisher's Note: All claims expressed in this article are solely those of the authors and do not necessarily represent those of their affiliated organizations, or those of the publisher, the editors and the reviewers. Any product that may be evaluated in this article, or claim that may be made by its manufacturer, is not guaranteed or endorsed by the publisher.

Copyright (C) 2022 Rovai, Twilley, Worthington and Riul. This is an open-access article distributed under the terms of the Creative Commons Attribution License (CC BY). The use, distribution or reproduction in other forums is permitted, provided the original author(s) and the copyright owner(s) are credited and that the original publication in this journal is cited, in accordance with accepted academic practice. No use, distribution or reproduction is permitted which does not comply with these terms. 